\title{
Analysis of Oily Sunflower Production in Turkey
}

\begin{tabular}{|c|c|}
\hline \multicolumn{2}{|c|}{$\begin{array}{l}{ }^{1} \text { Department of Agricultural Economics, Research Assistant, Çanakkale Onsekiz Mart University, } 17900 \text { Çanakkale, Turkey } \\
{ }^{*} \text { Corresponding author }\end{array}$} \\
\hline A R T I CLE INFO & A B S T R A C T \\
\hline $\begin{array}{l}\text { Keywords: } \\
\text { Oil seeds } \\
\text { Sunflower oil } \\
\text { Subsidy } \\
\text { Analysis } \\
\text { Turkey }\end{array}$ & $\begin{array}{l}\text { Oilseed crops are one of the product groups with high supply deficit in Turkey. According to } 2018 \\
\text { data, the total amount Turkey has paid for imports of sunflower and sunflower oil alone is US\$762 } \\
\text { million. According to the data of the same year, Turkey's oilseeds production amount is } \\
\text { approximately } 4 \text { million tons and the share in production of sunflower is } 48.62 \% \text {. In } 2018 \text {, the } \\
\text { country's oil sunflower production area is approximately } 650 \text { thousand ha, the production quantity is } \\
1.8 \text { million tons and the yield value is } 277 \mathrm{~kg} / \mathrm{da} \text {. The share of the provinces which are in the top five } \\
\text { in the country, with regard to total sunflower cultivation area and production quantity is about } 70 \% \text {. } \\
\text { While Konya takes the first place with } 408 \mathrm{~kg} / \text { da in the yield value obtained from the unit area, the } \\
\text { yield value is } 235 \mathrm{~kg} / \mathrm{da} \text { in the province of Tekirdag which has the highest cultivation area. } \\
\text { Considering the period between } 1998-2018 \mathrm{in} \text { Turkey, it is provided in oilseeds production increased } \\
\text { by } 66.43 \% \text { the most significant change in terms of the amount of this increase was realized in } \\
\text { sunflower production with share by } 126.65 \% \text {. So and so, in this period, the oilseed sunflower yield } \\
\text { has reached } 277.00 \mathrm{~kg} / \text { da from } 146.76 \mathrm{~kg} / \mathrm{da} \text {. Turkey's self-sufficiency rate is } 64.30 \% \text { in sunflower } \\
\text { production for oil, significant deficit in supply is available. Although the most effective support } \\
\text { application on the income of producers in sunflower production for oil is the deficiency payments, } \\
\text { there was no change in the unit price value announced in } 2017-2019 \text { period. In } 2018 \text {, considering the } \\
\text { average yield of } 277 \mathrm{~kg} / \mathrm{da} \text { sunflower for oil in Turkey deficiency payments in the production of } \\
\text { sunflower has a value per unit area } 110 \mathrm{TL} / \mathrm{da} \text { also increases. }\end{array}$ \\
\hline
\end{tabular}

Türk Tarım - Gıda Bilim ve Teknoloji Dergisi, 9(1): 56-62, 2021

\section{Türkiye'de Yağlık Ayçiçeği Üretiminin Analizi}

\begin{tabular}{|c|c|}
\hline M A K A L E B İ L G İ S İ & Ö Z \\
\hline $\begin{array}{l}\text { Anahtar Kelimeler: } \\
\text { Yağlik tohumlar } \\
\text { Yağlik ayçiçeği } \\
\text { Destekleme } \\
\text { Analiz } \\
\text { Türkiye }\end{array}$ & 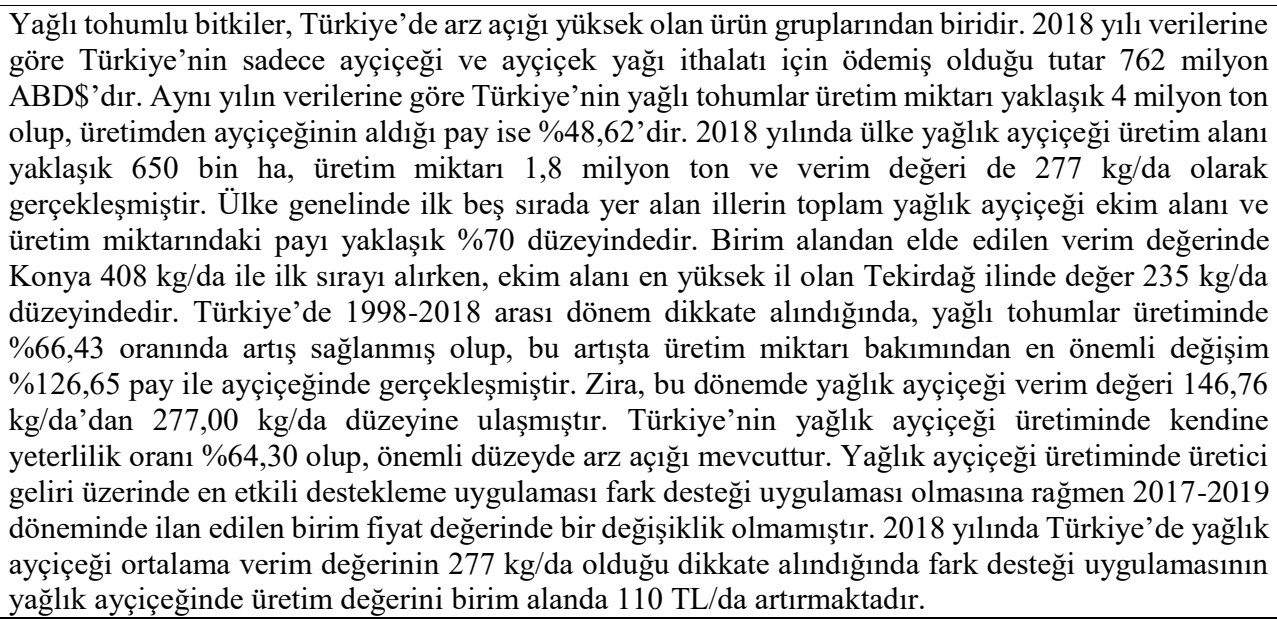 \\
\hline
\end{tabular}




\section{Giriş}

Dünya genelinde yağlı tohumlu bitkiler denildiğinde; soya fasulyesi, ayçiçeği, yerfistı̆̆ı, kolza, susam, aspir, zeytin, mısır, palmiye tohumu, hindistan cevizi, yağ keteni ve hint yağı bitkileri anlaşılmaktadır. Üretim miktarları dikkate alındığında ilk sıralarda soya, kolza, ayçiçeği, yerfistığı, pamuk tohumu ve palm çekirdeği bitkileri yer almaktadır. Türkiye'de üretimi yapılan yağlı tohumlar grubuna giren ürünler ise ayçiçeği, çiğit, yerfıstığ 1 , soya, haşhaş, aspir, susam ve kolzadır. Bu ürünler arasında çiğit (pamuk tohumu) sadece bir yağ bitkisi olmayıp ülke bitkisel yağ sanayinde önemli katkı sağlaması yönünden bu sinıflandırmada yer almaktadır.

Dünya genelinde önemli yağ bitkilerinden biri olan ayçiçeği Türkiye'de de en fazla ekim alanına ve üretim miktarına sahip yağlı tohum bitkisi olup, ülke bitkisel yağ ihtiyacının yaklaşık \%50'sini ayçiçeğinden elde etmektedir (Semerci, 2019a). Ayçiçeği, tohum içeriğindeki yüksek yağ miktarı (\%22-50) nedeniyle bitkisel ham yağ üretimi bakımından önemli bir yağ bitkisidir. Ayçiçeği yağı besin değeri yüksek olan yağlardan biridir. 2018 y1l verilerine göre dünya bitkisel ham yă üretiminin \%9,52'si ayçiçeğinden karşılanmaktadır. Türkiye'de ise bitkisel ham yă̆ üretiminin \%46,00'1 ayçiçeğinden karşılanmaktadır (USDA, 2020).

Ayçiçeği yağı, içerdiği doymamış yağ yağ asitleri oranının yüksek (\%69) olması açısından da beslenme değeri en yüksek bitkisel yağlardan birisidir. Yan ürün olarak \%4045 oranında elde edilen küspesi, \%30-40 oranında protein içermekte olup, değerli bir yem olarak hayvan beslenmesinde de kullanılmaktadır. Bunlara ek olarak ayçiçeği; yağ, sabun ve boya sanayinde değerlendirilmekte, sapları da yakacak olarak kullanılabilmektedir (Ticaret Bakanlığı, 2019). Bunun yanı sıra dünya ayçiçeği üretiminin $\% 2,60$ '1, Türkiye üretiminin de $\% 7,66$ 'sı çerezlik olarak tüketilmektedir (FAO, 2020).

Yağlık ayçiçeği yağ, küspe ve biyodizel üretim amaçlı kullanılmaktadır. Dünyada üretilen ayçiçeği tohumunun yaklaşık \%90'ı yağ için işlenmekte olup, dünya yağlı tohum üretiminde ayçiçeği 3. sırada yer almaktadır (TOB, 2020).

Yağlık ayçiçeği üretiminde maliyet analizi ve ürünün ticaretine yönelik bazı çalışmalar bulunmaktadır (Oğuz ve Altıntaş, 2002; Şahin ve ark., 2010; Düğmeci ve Çelik, 2020). Trakya'da ortalama verim değerinin 1,58 ton /ha olarak bulunduğu araştırmada maliyet unsurunun \%30,97'sini toprak hazırlama, \%29,50'sini bakım işleri $\% 31,18^{\prime}$ ini tarla kirası ve $\% 8,35^{\prime}$ lik kısmı da hasat ve harman giderlerinin oluşturduğu tespit edilmiştir (TEAE, 2001). Bayramoğlu ve ark. (2005) tarafindan yapılan bir araştırmada, Tokat ili Zile ilçesinde bazı önemli tarla bitkilerinin (ayçiçeği, buğday, soğan ve şekerpancarı) fiziki üretim girdileri ve bu ürünlerin birim alana üretim maliyetleri hesaplanmıştır.

Semerci ve Süzer (2007) tarafindan Edirne, Kırklareli ve Tekirdağ illerinde yürütülen ve ayçiçeği üretiminde girdi kullanımının ve etkinliğinin araştırıldığı çalışmada veriler 182 işletmeden elde edilmiştir. Gül ve ark. (2016) tarafindan yapılan çalışmada Türkiye'de ayçiçeği yağı tüketim ihtiyacını karşılayacak düzeyde olmadığından arz açığının önemli bir kısmının dış alım yoluyla karşılandığı vurgulanmıştır.
Sav ve Sayın (2016) çalışmalarında Türkiye'de yağlı tohumlar üretim potansiyeli, gelişimi, sektörün ekonomideki yeri ve diş ticareti ile sektörde yaşanan sorunlar ve uygulanan politikaları incelemiş ve yaşanan sorunlara ilişkin öneriler sunmuşlardır. Top ve Uçum (2016) tarafindan yapılan çalışmada ayçiçeğinde dünyada ve Türkiye'de; üretim, kullanım (tüketim), ihracat, ithalat, fiyatlar ile ilgili bulgular verilerek yılsonu stoklarında ortaya çıkan gerçekleşmelere ait durum tespiti yapılmış ve bir sonraki yıla ait muhtemel gelişmeler de tahmin olarak sunulmuştur.

Semerci (2012) ve Semerci (2016) tarafindan yapilan araştırmalarda; yağlık ayçiçeği üretiminin tarım işletmeleri için önemi, tarımsal desteklerin ayçiçeği üreticisinin geliri üzerine olan etkileri ve yağllk ayçiçeği üretiminde ürün maliyeti üzerinde etkili olan faktörler incelemiştir. Kadakoğlu ve Karlı (2019) çalışmalarında, dünyada ve Türkiye'ye yağlı tohum ekim alanı, üretim miktarı ve verim durumunu ortaya koyarak yağlık tohum üretiminin dış ticaret yapısını irdelemişlerdir. Ticaret Bakanlığ hazırlanan raporda ise; dünyada ve Türkiye'de ayçiçeği üretim bilgileri, ticareti, tüketimi, fiyat oluşumu verilmiştir. Yapılan çalışmada ayçiçeğine yönelik destekleme politikaları hakkında da ayrıntılı bilgi verilmiş̦ir.

Bu çalışmada Dünyada ve Türkiye'de yağlı tohumlar, bitkisel ham yağ üretimi ve ticaretine yönelik bilgilere yer verilmiştir. Çalışma kapsamında Türkiye genelinde yağlı tohumlar, özelinde ise yağlık ayçiçeği ve ayçiçeği yağı üretiminin 2000'li yıllardan sonraki değişim seyri araştırılmıştır. Çalışmada yağlık ayçiçeği üretiminde uygulanan destekleme politikalarının birim alandan elde edilen gelir üzerine yansıması incelenmiştir. Çalışma sonucunda ülke genelinde yağlık ayçiçeği üretiminde daha yüksek verimlilik düzeyinde ulaşılması ve üretici gelirinin artırılmasına yönelik önerilerde bulunulmuştur.

\section{Materyal ve Yöntem}

Çalışmada kullanılan istatistiki veriler; Türkiye İstatistik Kurumu (TÜIK), Amerika Birleşik Devletleri Tarım Bakanlığı (USDA), Birleşmiş Milletler Gıda ve Tarım Örgütü (FAO) ile Türkiye Bitkisel Yağ Sanayicileri Derneği (BYSD) verilerinden elde edilmiştir. Bununla birlikte çalışmada konu ile ilgili kurum ve kuruluşların yayınları, komisyon raporları ve sektör raporlarından da yararlanılmıştır.

Çalışmada, 2013-2018 döneminde dünyada ve 19982018 döneminde Türkiye'de genelde yağlı tohumlar ve özelde ayçiçeği üretim bilgileri Çizelgeler halinde verilmiştir. 1998-2018 döneminde Türkiye'de üretilen yağlı tohumlu bitkilerin değişimi irdelenmiş, hazırlanan Çizelgede 20 yıllık süreçte bu ürünlerin en düşük ve en yüksek seviyeye ulaştıkları yıllar da belirlenmiştir. Türkiye'nin ayçiçeği ve ayçiçeği yağı dış ticareti, 2012-2018 dönemi dikkate alınarak incelenmiştir.

$\mathrm{Bu}$ çalışmada ayrıca, 2018 yılı yağlık ayçiçeğinde elde edilen ortalama verim değeri dikkate alınarak bu üründe uygulanan tarımsal desteklerin (özellikle fark desteği uygulamasının) ürün geliri üzerindeki etkisi incelenmiştir. Çalışmada konu ile ilgili olarak daha önce yapılan çalışmalardan elde edilen bulgular ile bu çalışmada hesaplanan değerlerin karşılaştırılması yapılmıştır. 
Çizelge 1. Dünya yağlı tohumlar üretimi (milyon ton) Table 1. Oilseed production in the world (million tons)

\begin{tabular}{|c|c|c|c|c|c|c|}
\hline \multirow{2}{*}{ Yillar } & \multicolumn{6}{|c|}{ Yillar } \\
\hline & 2013 & 2014 & 2015 & 2016 & 2017 & 2018 \\
\hline Soya & 277,5 & 306,2 & 323,2 & 335,5 & 352,6 & 348,7 \\
\hline Kolza & 73,1 & 74,5 & 70,2 & 68,1 & 76,2 & 75 \\
\hline Ayçiçeği & 45,3 & 42,6 & 44,3 & 47,5 & 47,9 & 52 \\
\hline Yerfistığ 1 & 46,4 & 45,6 & 44,4 & 44,9 & 47,1 & 46 \\
\hline Pamuk Tohumu & 45,4 & 46,7 & 39,9 & 41,5 & 43,3 & 41,2 \\
\hline Susam & 6,0 & 6,3 & 5,7 & 5,6 & 5,5 & 6,0 \\
\hline Aspir & 0,7 & 0,7 & 0,8 & 0,9 & 0,7 & 0,6 \\
\hline Toplam & 494,5 & 522,5 & 528,5 & 544,1 & 573,3 & 569,4 \\
\hline
\end{tabular}

Kaynak: FAO, 2020.

Çizelge 2. Dünya bitkisel ham yă̆ üretimi (milyon ton)

Table 2. Vegetable crude oil production in the world (million tons)

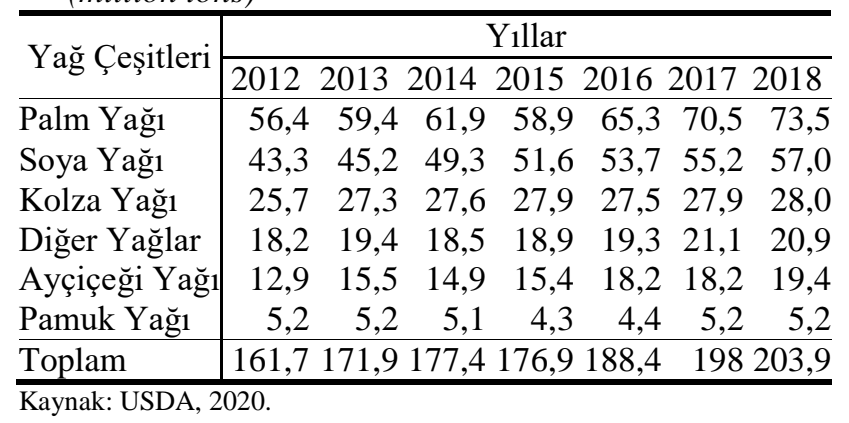

Çalı̧̧a kapsamında Türkiye'de 2008-2019 döneminde yağlı tohumlarda uygulanan fark desteği birim fiyatlarında meydana gelen değişim de incelenmiştir.

\section{Araştırma Bulguları}

Dünya Yağlı Tohumlar ve Bitkisel Ham Yağ Üretimi

Dünya Gıda ve Tarım Örgütü (FAO)'nün 2018 y1lı verilerine göre Dünya yağlı tohumlar üretimi 569.427.128 ton/yıl olup, üretimde ilk sirada $\% 61,24$ pay ile soya gelmektedir. Yağlık ayçiçeği ise 51.956.173 ton üretim miktarı ile kolzadan sonra $\% 9,12$ 'lik pay ile 3 . sirada yer almıştır (Çizelge 1).

Dünya yağlı tohumlar üretiminde ilk sırada Amerika Birleşik Devletleri (ABD) almaktadır. ABD'yi sırasıyla Brezilya, Arjantin, Çin ve Hindistan takip etmekte olup, söz konusu beş ülkenin dünya üretimindeki payı yaklaşı olarak \%70'tir. Dünya ayçiçeği üretiminde ise Ukrayna 14.165.170 ton ile ilk sirada ve Rusya Federasyonu 12.755 .725 ton ile ikinci sırada bulunmaktadır (FAO, 2020). 2018 y1l itibariyle dünya genelinde 203.933.000 ton bitkisel ham yağ üretilmiştir. Toplam üretim miktarında palm yağı \%36,03'lük pay ile ilk sırada yer almaktadır. Ayçiçek yağı ise soya ve kolza yağının ardından \%9,54'lük pay ile dördüncü sırada yer almıştır (Çizelge 2). Dünya bitkisel ham yağ üretiminde Endonezya, Çin ve Malezya ilk üç sırayı paylaşmaktadırlar.

Dünya yağlık ayçiçeği üretimi 2018 yılında 20.074 .000 ton olarak gerçekleşmiş̧ir. Üretimde \%32,61 ile Ukrayna, $\% 25,06$ ile Rusya Federasyonu ve \%18,36 pay ile AB-28 ülkeleri ilk üç sırada yer almaktadırlar (Ticaret Bakanlığı, 2019).

\section{Dünya'da ve Türkiye'de Ayçiçeği Yağı Tüketimi}

Dünya ayçiçeği yağı tüketimi 2018 yılı itibariyle 18.698.000 ton düzeyindedir. Belirtilen miktarın yaklaşık 4.960.000 tonu Avrupa Birliği ülkelerinde, 2.450.000 tonu Rusya Federasyonu'nda tüketilirken, Türkiye'de tüketim 1.094 .00 ton düzeyinde gerçekleşmiştir. Ayçiçeği yağ üretiminde Türkiye'nin yıllık yağlık ayçiçeği kırma kapasitesi ise 2018 yllinda 2.160 .000 ton olarak gerçekleşmiştir (Ticaret Bakanlığı, 2019).

\section{Türkiye'de Yağlı Tohumlar Üretimi}

Türkiye'de yağlı tohumlar üretimi (keten ve kenevir alanları dikkate alınmadığında) FAO'nın 2018 yılı verilerine göre 9.449 .710 da alanda gerçekleşmiştir. Üretim alanlarında \%77,69'lik pay ile ayçiçeği ilk sırayı almıştır. Aynı yıl yağlı tohumlar grubunda değerlendirilen ürünlerin toplam miktarı 4.009.492 ton olmuştur. Üretimde ilk üç sırayı ayçiçeği $(\% 48,62)$, çiğit $(\% 38,46)$ ve yerfıstığı $(\% 4,34)$ almıştır (Çizelge 3).

Türkiye'de son 20 yıllık dönemde (1998-2018) yağlı tohumlar üretim miktarında $\% 66,43$ oranında artış sağlanmış olup, yağlık ayçiçeği üretim miktarındaki artış ise $\% 126,65$ düzeyinde gerçekleşmiştir. Belirtilen dönemde birim alandan elde edilen yağlık ayçiçeği verim değeri $146,76 \mathrm{~kg} / \mathrm{da}$ düzeyinden $277 \mathrm{~kg} / \mathrm{da}$ düzeyine ulaşmıştır. Üretim miktarı bakımından ayçiçeğine en yakın yağlı tohum ise çiğit olmuştur. Diğer ürünlerde ise 2018 yılı üretim miktarı 173.000 tonun altında kalmıştır. Çizelge 3 Türkiye'de en önemli yağ bitkisinin ayçiçeği olduğunu açıkça ortaya koymaktadır.

\section{Türkiye'de Ayçiçeği Üretimi}

2018 yllı TÜiK verilerine göre Türkiye'de toplam ayçiçeği ekim alanı 7.344 .651 da, üretim miktarı ise 1.949.229 ton olmuştur. Ayçiçeği üretim alanlarının $\% 88,35$ 'ini ve üretim miktarının $\% 92,34$ 'ünü yağlık ayçiçeği oluşturmaktadır (Çizelge 4). Türkiye, 2018 y1lı verilerine göre dünya ayçiçeği ekim alanlarının $\% 2,75$ 'ini, üretim miktarının da $\% 3,75^{\prime}$ ini karşılamaktadır. Türkiye'de ayçiçeği verimi $277 \mathrm{~kg} / \mathrm{da}$ olup dünya ortalama değerinden $(194,82 \mathrm{~kg} / \mathrm{da}) \quad \% 42,18$ oranında daha yüksektir (FAO, 2020).

2018 yılında Türkiye'de 56 ilde yağlık ayçiçeği üretimi gerçekleşmiştir. Belirtilen yılda yaklaşık 6,5 milyon da alanda 1,8 milyon ton yağlık ayçiçeği üretilmiştir. Yağlık ayçiçeği üretiminde Tekirdağ ilk sırayı alırken, Konya ikinci sırada, Edirne ili ise üçüncü sırada yer almıştır. Ülke genelinde ilk beş sırada yer alan illerin toplam ekim alanındaki ve üretim miktarındaki payı yaklaşık \%70 düzeyindedir. İlk beş il arasında verim değeri en yüksek il yaklaşık $408 \mathrm{~kg} / \mathrm{da}$ ile Konya ilidir. Üretim alanı en yüksek il olan Tekirdağ'da ise verim değeri yaklaşık $235 \mathrm{~kg} / \mathrm{da}$ düzeyindedir.

\section{Türkiye'nin Yağllk Ayçiçeği Dış Ticareti}

Türkiye'nin yağlık ayçiçeği dış ticaret verileri Çizelge 5'te verilmiştir. 2012-2018 dönemi incelendiğinde ülke genelindeki ayçiçeği üretimine paralel olarak yağlık ayçiçeği ithalat miktarının $\% 5,58$ oranında, ithalat değerinin de $\% 18,66$ oranında azaldığı, ihracatın büyük bölümünü ise yağlı ayçiçeğinin oluşturduğu anlaşılmaktadır. 
Çizelge 3. Türkiye'de son 20 y1llık dönemde yağlı tohumlar üretimi (ton)

Table 3. Oilseeds production in Turkey in the last 20 years (ton)

\begin{tabular}{l|ccccccc}
\hline \multirow{2}{*}{ Kriter } & \multicolumn{7}{c}{ Y1llar } \\
\cline { 2 - 8 } & 1998 & 2002 & 2007 & 2012 & 2017 & 2018 & Pay $(\%)$ \\
\hline Ayçiçeği & 860.000 & 850.000 & 854.407 & 1.370 .000 & 1.964 .385 & 1.949 .229 & 48,62 \\
Çiğit & 1.334 .778 & 1.457 .122 & 1.320 .831 & 1.373 .440 & 1.470 .000 & 1.542 .000 & 38,46 \\
Yerfistı̆̆ & 90.000 & 90.000 & 86.409 & 122.780 & 165.330 & 173.835 & 4,34 \\
Soya & 60.000 & 75.000 & 30.666 & 115.000 & 140.000 & 140.000 & 3,49 \\
Kolza & 300 & 1.500 & 28.727 & 110.000 & 60.000 & 125.000 & 3,12 \\
Aspir & 72 & 25 & 2.280 & 19.500 & 50.000 & 35.000 & 0,87 \\
Haşhaş & 27.964 & 19.000 & 8.981 & 3.844 & 15.244 & 26.991 & 0,67 \\
Susam & 34.00 & 22.000 & 20.010 & 16.221 & 18.410 & 17.437 & 0,43 \\
\hline Toplam & 2.409 .112 & 2.516 .649 & 2.354 .318 & 3.130 .785 & 3.883 .369 & 4.009 .492 & 100,00 \\
\hline Kaynak: FAO, 2020. & & & & & &
\end{tabular}

Çizelge 4. Türkiye'de yağlık ayçiçeği üretim bilgileri (2018)

Table 4. Information of sunflower production for oil in Turkey (2018)

\begin{tabular}{l|ccc}
\multicolumn{1}{c}{ Yerleşim Birimi } & Hasat Edilen Alan (da) & Üretim (ton) & Verim (kg/da) \\
\hline Tekirdağ & 1.481 .286 & 347.502 & 234,59 \\
Konya & 727.561 & 296.591 & 407,65 \\
Edirne & 954.502 & 237.136 & 248,44 \\
Kirklareli & 750.021 & 193.169 & 257,55 \\
Adana & 521.214 & 176.639 & 338,90 \\
Toplam & 4.434 .584 & 1.251 .037 & 282,11 \\
Türkiye & 6.489 .344 & 1.800 .000 & 277,38 \\
Ilk 5 ilin Payı \% & 68,34 & 69,50 & - \\
\hline
\end{tabular}

Kaynak: TB, 2019; TÜiK, 2020.

Çizelge 5. Türkiye'nin yağlık ayçiçeği ithalat ve ihracat değerleri

Table 5. Turkey's import and export values of sunflower for oil

\begin{tabular}{l|cccc}
\hline \multirow{2}{*}{ Yillar } & \multicolumn{3}{c}{ İthalat } & \multicolumn{2}{c}{ İhracat } \\
\cline { 2 - 5 } & Miktar (ton) & Değer (000\$) & Miktar (ton) & Değer (000 \$) \\
\hline 2012 & 754.162 & 443.959 & 40.148 & 101.082 \\
2013 & 710.843 & 474.002 & 32.311 & 101.091 \\
2014 & 556.909 & 406.155 & 33.351 & 111.265 \\
2015 & 340.326 & 237.984 & 30.618 & 76.339 \\
2016 & 382.329 & 263.005 & 47.498 & 120.415 \\
2017 & 640.442 & 356.471 & 57.328 & 138.035 \\
$2018^{*}$ & 712.112 & 361.101 & 47.474 & 114.590 \\
\hline
\end{tabular}

Kaynak: FAO, 2020; ITC, 2020.

Çizelge 6. Türkiye'nin ayçiçek yağı ithalat ve ihracat değerleri

Table 6. Turkey's import and export value of sunflower oil

\begin{tabular}{l|cccc}
\hline \multirow{2}{*}{ Y1llar } & \multicolumn{3}{c}{ İthalat } & \multicolumn{2}{c}{ İhracat } \\
\cline { 2 - 5 } & Miktar (ton) & Değer (000 ABD\$) & Miktar (ton) & Değer (000 ABD\$) \\
\hline 2012 & 743.435 & 988.428 & 271.033 & 416.572 \\
2013 & 632.054 & 918.364 & 345.671 & 495.132 \\
2014 & 829.157 & 1.199 .484 & 664.077 & 788.514 \\
2015 & 798.170 & 1.101 .230 & 617.924 & 680.055 \\
2016 & 738.405 & 1.015 .540 & 599.663 & 636.101 \\
2017 & 660.682 & 661.019 & 537.436 & 548.735 \\
$2018^{*}$ & 498.357 & 400.501 & 416.974 & 421.765 \\
\hline
\end{tabular}

Kaynak: FAO, 2020; *ITC, 2020.

Çizelge 5'e göre; 2012-2018 döneminde ayçiçek yağ ithalat miktarının \%32,94 oranında, ithalat değerinin ise \%59,48 oranında azaldığı görülmektedir. Aynı dönem itibariyle, yağlık ayçiçeği ihracat miktarı \%53,85 oranında, ihracat değeri ise \%1,25 oranında artış gösterdiği anlaşılmaktadır. Türkiye'nin ayçiçeği yağı diş ticaret değerleri Çizelge 6'da gösterilmiştir. 2012-2018 döneminde ayçiçeği yağı ithalatına yaklaşık 6,3 milyar
ABD\$ harcama yapmış, aynı dönemde yaklaşık 4,0 milyar ABD\$ gelir elde etmiştir.

\section{Türkiye’nin Yağlı Tohumlarda Kendine Yeterlilik}

\section{Durumu}

TÜİK tarafindan yapılan ve 2017 yılı verilerinin kullanıldığı çalışmada ülkenin kendine yeterlilik durumu; pamuk çiğidinde $\% 101,00$, kolzada $\% 70,30$, ayçiçeğinde $\% 64,30$ ve soyada \%4,80 olarak hesaplanmıştır (Çizelge 7). 
Çizelge 7. Türkiye'de yağlı tohumlu bitkilerde denge durumu (2017)

Table 7. Oilseed crops in balance situation in Turkey (2017)

\begin{tabular}{l|cccc}
\hline \multicolumn{1}{c|}{ Kriterler } & Soya & Pamuk (Çiğit) & Kolza & Ayçiçeği \\
\hline Üretim (ton) & 140.000 & 1.470 .000 & 60.000 & 1.964 .385 \\
Ekilen Alan (Hektar) & 31.670 & 501.853 & 16.520 & 779.622 \\
Üretim Kayıpları (Ton) & 1.120 & 29.400 & 780 & 15.715 \\
Arz=Kullanım (Ton) & 2.916 .335 & 1.441 .016 & 91.534 & 4.115 .440 \\
Kullanılabilir Üretim (Ton) & 138.880 & 1.440 .600 & 59.220 & 1.948 .670 \\
İthalat (Ton) & 2.777 .455 & 416 & 32.314 & 2.166 .770 \\
Ab 27-28 İthalat (Ton) & 140.000 & 1.470 .000 & 60.000 & 1.964 .385 \\
Yurt Içi Kullanım (Ton) & 2.896 .007 & 1.426 .564 & 84.229 & 3.032 .188 \\
Tüketim (Ton) & 38.043 & 1.338 .728 & 82.214 & 2.959 .850 \\
Tohumluk Kullanım (Ton) & 3.167 & 20.074 & 330 & 11.694 \\
Yemlik Kullanım (Ton) & 1.716 .392 & - & - & - \\
Endüstriyel Kullanım (Ton) & 1.102 .205 & - & - & - \\
Kayıplar (Ton) & 36.200 & 67.762 & 1.685 & 60.644 \\
İhracat (Ton) & 20.328 & 13.280 & 7.305 & 1.202 .958 \\
Ab 27-28 İhracat (Ton) & - & 5.611 & 3.413 & 34.554 \\
Stok Değişimi (Ton) & - & 1.172 & - & -119.706 \\
Kişi Başı Tüketim (Kg) & 0,50 & 16,60 & 1,00 & 36,60 \\
Yeterlilik Derecesi (\%) & 4,80 & 101,00 & 70,30 & 64,30 \\
\hline
\end{tabular}

Kaynak: TÜiK, 2020.

Çizelge 8. Türkiye'de yağlık ayçiçeği ürününe verilen destekleme birim fiyatları

Table 8. Given the sunflower products for oil support unit prices in turkey

\begin{tabular}{l|cccc}
\hline \multicolumn{1}{c}{ Destek Türü } & \multirow{2}{*}{ Birimi } & 2017 & Ylllar \\
\cline { 3 - 5 } & & 17,00 & 2018 & 2019 \\
\hline Mazot Desteği & (TL/da) & 4,00 & 19,00 & 26,00 \\
Gübre Desteği & (TL/da) & 4,00 & 4,00 \\
Fark Desteği & (TL/kg) & 0,40 & 0,40 & 0,40 \\
Toprak Analizi Desteği $(*)$ & (TL/da) & 0,80 & 0,80 & 0,80 \\
\hline
\end{tabular}

Kaynak: Resmî Gazeteler, 2017 - 2019. (*): Tarım ve Orman Bakanlığı tarafindan akredite edilen toprak analiz ve tahlil laboratuvarlarına ödeme yapılmaktadır.

Çizelge 9. Türkiye'de fark ödemesi desteği birim fiyatları $(\mathrm{krş} / \mathrm{kg})$

Table 9. Deficiency payment support unit prices in Turkey $(\mathrm{krs} / \mathrm{kg})$

\begin{tabular}{l|cccccc}
\hline Ürünler & Kütlü Pamuk & Soya & Aspir & Kanola & Yağlik Ayçiçeği & Dane Misır \\
\hline 2008 & 27 & 20,7 & 20,7 & 20,7 & 18,9 & 3,6 \\
2009 & 42 & 27,5 & 25 & 23 & 21 & 4 \\
2010 & 42 & 35 & 30 & 27,5 & 23 & 4 \\
2011 & 42 & 50 & 40 & 40 & 23 & 4 \\
2012 & 46 & 50 & 40 & 40 & 24 & 4 \\
2013 & 50 & 50 & 45 & 40 & 24 & 4 \\
2014 & 55 & 50 & 45 & 40 & 30 & 4 \\
2015 & 65 & 50 & 45 & 40 & 30 & 4 \\
2016 & 75 & 60 & 55 & 50 & 40 & 2 \\
2017 & 80 & 60 & 55 & 50 & 40 & 3 \\
2018 & 80 & 60 & 55 & 50 & 40 & 3 \\
2019 & 80 & 60 & 55 & 50 & 40 & 3 \\
Değişim (2019/2008) & 196,29 & 189,86 & 165,7 & 141,6 & 111,6 & $-16,67$ \\
\hline
\end{tabular}

Kaynak: Resmî Gazeteler, 2008-2019.

\section{Yă̆lık Ayçiçeğinde Fiyat Oluşumu}

Türkiye'de yağlık ayçiçeği alımında tarım satış kooperatiflerinin önemli payı bulunmaktadır. Ülkenin önemli tarım satış kooperatifleri birliklerinden biri olan Trakya Birlik 2018/19 sezonunda 276.773 ton Karadeniz Birlik ise 23.528 ton alım gerçekleştirmiştir (Ticaret Bakanlığı, 2019). Belirtilen iki birliğin alım miktarı Türkiye yağlık ayçiçeği üretim miktarının \%14,20'sine denk gelmektedir.

Trakya Birlik Yönetim Kurulu'nca 2019/2020 iş y1lında ayçiçeğine uygulanan ön alım fiyatı $\% 40$ standart yağ oranlı ayçiçeği ürünü için 2.500,00 TL/ton fiyat üzerinden uluslararası sözleşme kriteri olan \%44 yağ oranlı ayçiçeği ürünü için alım fiyatı $2.650 \mathrm{TL} /$ ton olarak belirlenmiştir. Hesaplanacak yă primleri çerçevesinde $\% 50$ yağ oranlı ayçiçeği ürünü için fiyat 2.875,00 TL/ton'a karşıllk gelmekte olup, bu doğrultuda üretici ortaklara $\% 40$ yağlı baz ürün üzerinden her $\% 1$ ilave yağ oranı için $\% 1,5$ oranında $37,5 \mathrm{TL} /$ ton'a tekabül eden yağ primi ödeneceği bildirilmiştir (Trakya Birlik, 2019). 


\section{Türkiye'de Ayçiçeği Ürününe Verilen Destekler}

Türkiye'de yağlık ayçiçeğinin üretim merkezi konumundaki Trakya'da yer alan Tekirdağ ve Kırklareli illerinde yürütülen çalışmalar bu illerde yağlık ayçiçeği üretiminde özellikle fark desteği uygulamasının ürünün GSÜD, brüt kar ve net kar değerini ne derece olumlu yönde etkilediğini ortaya koymaktadır (Semerci, 2019a,b).

Kırklareli ilinde 2017 yılında yapılan bir çalı̧̧mada $\boldsymbol{y}$ ağlık ayçiçeği üretiminde 2,41 ton/ha verim karşıllı̆̆ında ürünün gayri safi üretim değeri 1.180,9 ABD\$/ha iken bu değere diğer destekler eklendiğinde (fark desteği $265 \$$ +gübre desteği 10,6 ABD\$ + mazot desteği 45,1 $\mathrm{ABD}$ +toprak analiz desteği 2,1 ABD\$) birim alandan elde edilen gelirin $1.503,8 \mathrm{ABD} \$ / \mathrm{ha}$ düzeyine ulaştığ 1 hesaplanmıştır. Diğer bir ifade ile tüm desteklerle birlikte yağlık ayçiçeğinden birim alandan elde edilen gelirde 322,8 ABD\$/ha'lık bir artış sağlanması mümkündür. $\mathrm{Bu}$ durumda tarımsal destekleme uygulamalarıyla yağlık ayçiçeği üretiminde birim alandan elde edilen gelirde $\% 27,37$ oranında artış sağlanmakla birlikte, sadece fark desteği uygulaması ile sağlanan artış \%22,45'i bulmaktadır. Çalışmada yağlık ayçiçeği üretiminde ortalama brüt kar değeri $812,96 \$ /$ ha, net kar ise 451,27 ABD \$/ha olarak belirlenmiştir. Birim alana maliyet 994,73 $\mathrm{ABD} \$$ ha, ton başına maliyet ise $432,49 \mathrm{ABD}$ \$ olarak hesaplanmıştır. Hesaplamalarda yağlık ayçiçeği fiyatına ayrıca ton başına verilen 110 ABD\$ fark desteği de eklenmiştir. İncelenen işletmelerde fark desteği uygulaması üretici gelirinde hektar başına 265,10 ABD\$ düzeyinde artış sağlamıştır. Diğer bir ifade ile üreticinin yağlık ayçiçeği gelirinde fark desteğinin payı ise $\% 22,45$ olmuştur (Semerci, 2019a).

Tekirdağ ilinde 2017 yılında yapılan bir çalışmada ise 2,30 ton/ha verim karşıllı̆ında ürünün gayri safi üretim değeri $1127 \mathrm{ABD} \$ /$ ha iken bu değere diğer destekler eklendiğinde (fark desteği 253 ABD $\$$ +gübre desteği 10,6 $\mathrm{ABD} \$+$ mazot desteği 45,1 ABD $\$+$ toprak analiz desteğ 2,1 ABD\$) 1437,8 ABD\$/ha düzeyinde gelir elde edilebildiği hesaplanmıştır. Diğer bir ifade ile desteklerle yağlık ayçiçeğinden birim alandan elde edilen gelirde 310,8 ABD \$/ha'lık bir artı̧ olmaktadır. Bu durumda tarımsal destekleme uygulamalarıyla birim alandan elde edilen gelirde \%21,62 oranında artış sağlanmaktadır. Sadece fark desteği uygulaması ile yağlık ayçiçeği gelirinde $\% 18,33$ düzeyinde artı̧s sağlanmıştır. Çalışmada, yağlık ayçiçeğinde ortalama brüt kar değeri 781,3 $\mathrm{ABD}$ /ha, net kar ise 415,7 ABD \$/ha olarak belirlenmiştir. Birim alana maliyet $957 \mathrm{ABD}$ /ha, ton başına maliyet ise 420 ABD\$ olarak hesaplanmıştır. Hesaplamalarda yağlık ayçiçeği fiyatına ayrıca ton başına verilen 110 ABD\$ fark desteği de eklenmiştir. İncelenen işletmelerde fark desteği uygulaması üretici gelirinde hektar başına 253 ABD\$ düzeyinde artış sağlamıştır. Diğer bir ifade ile üreticinin yağlık ayçiçeği gelirinde fark desteğinin payı ise $\% 18,33$ olmuştur (Semerci, 2019b).

Türkiye'de ayçiçeği üretimine verilen desteklerin ayrıntısı Çizelge 8 'de yer almaktadır. Fark (prim) desteği, verilen destekler içinde en önemli kalemi oluşturmaktadır. Türkiye'de 2018 yılı yă̆lık ayçiçeği ortalama verim değeri $277 \mathrm{~kg} / \mathrm{da}$ olduğu dikkate alınırsa birim alana fark desteğinin $(277 \times 0,40 \quad$ kuruş $) \quad 110,80 \quad$ TL olduğu anlaşılmaktadır. Çizelge 8 incelendiğinde 2017-2019 döneminde, üreticinin en önemli gelir kaynağı ya da maliyeti düşürme unsurlarından biri olan fark desteğinde bir artış olmadığı görülmektedir. Aynı dönemde mazot desteği birim fiyatı $\% 52,94$ oranında artı̧ göstermesine rağmen gübre desteği birim fiyatı aynı düzeyde tutulmuştur. 2019 yılı dikkate alındığında, yağlık ayçiçeği üretiminde alan bazlı desteklerin tutarı (mazot ve gübre desteği) 30,00 TL/da'dır.

\section{Yağllk Ayçiçeğinde Fark Desteğinin Birim Fiyatları}

Türkiye'de yağllk ayçiçeği üretimine uygulanan fark desteği birim fiyatları Çizelge 9'da verilmiştir. Çizelge 9 incelendiğinde 2008-2019 döneminde birim fiyat artı̧ı en yüksek olan ürün kütlü pamuk, en düşük artış sağlanan olan ürün ise dane mısır olmuştur. Yağlık ayçiçeğinde fark ödeme desteği birim fiyatındaki artış ise \%111,64 olmuştur.

\section{Sonuç ve Öneriler}

Türkiye'de bitkisel yağ üretiminde ayçiçeği yağ 1 yaklaşı \% 50 'lik pay ile ilk sırada yer almaktadır. Bu durum ülke genelinde yağlık ayçiçeği üretimini ve desteklemesini diğer ürünlere göre daha ayrıcalıklı hale getirmektedir. Yapılan çalışma ülke genelinde bitkisel yağ arzının talebi karşılamaktan oldukça uzak olduğunu ortaya koymaktadır. $\mathrm{Bu}$ durum ayçiçeği yağında daha belirgin bir şekilde görülmektedir. Çalışma verileri Türkiye'de ayçiçeği yağında arzın talebi karşılama oranının \%65'ler düzeyinde olduğunu göstermektedir. Tüketime esas yaklaşı 900 bin ton ayçiçeği yağının yaklaşık 500-550 bin tonu yurtiçi ülke üretiminden elde edilmektedir. Tabep ve arz arasında meydana gelen açık ise yağllk ayçiçeği tohumu ya da ham ayçiçeği yağı ithalatıyla kapatılmaya çalışılmaktadır. $\mathrm{Bu}$ nedenle Türkiye'nin yağlı tohum ihtiyacının ülke içinden karşılanması son derece önemli olup, ciddi bir ithalat kalemi olan yağlı tohumlarda, üretimi artırıcı politikaların hayata geçirilmesi zorunluluk arz etmektedir.

Türkiye'nin yağlı tohum ihtiyacının ülke içi kaynaklarıyla karşılanması son derece önemli olup, ciddi bir ithalat kalemi olan yağlı tohumlarda, üretimi artırıcı politikaların hayata geçirilmesi zorunluluk halini almıştır. Uygulanmakta olan tarımsal destekleme politikalarının ise dünya şartlarıyla rekabet edebilecek düzeyde olması gerekmektedir.

Yağllk ayçiçeği üreticilerinin gelirlerinin belirli bir düzeyin altına düşürülmemesi için öncelikle ülke içinde üretilen yağlık ayçiçeğinin tamamının işlenmesinden sonra dış alıma gidilmelidir.

Ayçiçeği üretiminde kullanılan tohumluk çeşitleri genetik olarak orobanşa dayanıklı, IMI grubu ilaçlara dayanıklı ve orobanşa dayanıksız çeşitler olarak 3 grupta değerlendirilmektedir. Birim alandan daha yüksek verim elde edebilmek için verim değeri düşük olan orobanşa dayanıksız çeşitlerin üretiminin kaldırılması ve diğer çeşitlere yönelinmesi gerekmektedir.

Yağlık ayçiçeği üretiminde kullanılacak gübreler mutlaka bitki ihtiyacını karşılayacak düzeyde olması gerekmektedir. Diğer bir ifade ayçiçeği üretiminde gübre kullanımında kaynak kullanım etkinliğinin sağlanabilmesi gerekmektedir. Bu amaca yönelik olarak sadece ayçiçeği üretiminde kullanılabilecek özel formulasyona sahip gübre çeşidinin geliştirilmesi ve kullanımının yaygınlaştırılması birim alandan elde edilen verimin artırılmasında önemli bir faktör olabilir. 
Yapılan çalışmalar ülke genelinde yağlık ayçiçeği üretiminde birim alandan elde edilen verim değerinin daha yüksek olabileceğini ortaya koymaktadır. $\mathrm{Bu}$ farklılı̆̆ oluşturabilmenin en önemli yolu ise yağlık ayçiçeği üretiminin sulu şartlarda yapılmasını sağlayabilmektir. Yürütülen birçok çalışma Trakya'da yağlık ayçiçeği üretiminin kuru şartlarda olduğunu ortaya koymaktadır. Bu durum verim değerinin de düşük olmasına neden olmaktadır. Bu bakımdan özellikle yağlık ayçiçeği üretiminde ilk beş sırada yer alan illerde yağlık ayçiçeği üretiminde kuru şartlardan sulu şartlarda üretime geçilmesi yönünde politikaların yönlendirilmesi ve destekleme politikasında bu yönde yoğunlaşılması üretimi artıracağ gibi üretici gelirinde de önemli artışlara neden olacaktır.

Trakya genelinde uygulanan ayçiçeği buğday münavebesinde fiyat paritesi (ayçiçeği /buğday) özel önem taşımaktadır. Yapılan bazı çalışmalarda paritenin 2 ve bazen de özellikle 2,5'in üzerinde olduğu yıllarda üreticilerin ayçiçeği üretimine yöneldiğini ortaya koymaktadır. Türkiye'de yağlık ayçiçeğinin en önemli alıcısı konumunda olan Trakyabirlik ve Karadenizbirlik'in fiyat paritesine dikkat edecek şekilde yağlık ayçiçeği alım fiyatını belirlemeleri gerekmektedir.

Yağlı ayçiçeği üretiminde üretici gelirinin artırılmasında ya da ürün maliyetinin düşürülmesinde en önemli faktör fark desteği uygulamasıdır. Ülke genelinde yağlık ayçiçeği üretiminin artırılması için; özellikle Trakya kesimi dışındaki bölgelerde yağlık ayçiçeği üretimine verilen fark desteği daha üst düzeyde tutulmalıdır. Yağlık ayçiçeği üretiminde yağ oranı yüksek, suya ve gübreye daha yüksek düzeyde reaksiyon gösteren çeşitlerin ıslahına ve bu çeşitlerin yaygınlaştırılmasına özel önem verilmelidir. Bu konuda Ar-Ge faaliyeti gösteren özel ve kamuya ait araştırma kurum ve kuruluşları mutlaka desteklenmelidir.

\section{Kaynaklar}

Bayramoğlu Z, Göktolga ZG, Gündüz O. 2005. Tokat İli Zile İlçesinde Yetiştirilen Bazı Önemli Tarla Ürünlerinde Fiziki Üretim Girdileri ve Maliyet Analizleri, Tarım Ekonomisi Dergisi, 11(2): 101-109.

Düğmeci HY, Çelik Y. 2020. Konya İli Çumra İlçesinde Yağlık Ayçiçeği Üretim Maliyetinin Tespiti Üzerine Bir Araştırma. Türk Tarım ve Doğa Bilimleri Dergisi 7(3): 682-690, 2020.

FAO, 2020. Birleşmiş Milletler Gida ve Tarım Örgütü. FAOSTAT. Erişim: http://www.fao.org/faostat/en/\#data [Erişim tarihi: 10.02.2020]

Gül V, Öztürk E, Polat T. 2016. Günümüz Türkiye’sinde Bitkisel Yağ Açığını Kapatmada Ayçiçeğinin Önemi. Alınteri Dergisi, 30(B): 70-76.

ITC, 2020. International Trade Center. TRADEMAP. Erişim: https://www.trademap.org/Index.aspx [Erişim tarihi:10.02. 2020]

Kadakoğlu B, Karlı B. 2019. Türkiye'de Yağlı Tohum Üretimi ve Dış Ticareti. Akademik Sosyal Araştırmalar Dergisi, 7(96): 324-341.

Oğuz C, Altıntaş Ö. 2002. Kırıkkale İlinde Çerezlik ve Yağlık Ayçiçeği Yetiştiriciliğinin Üretim Maliyeti ve Fonksiyonel Analizi. SÜ. Ziraat Fakültesi Dergisi 16 (29): 39-47.
Resmî Gazete 2008-2019. Bitkisel Üretim Destekleme Birim Fiyatı. Erişim: https://www.resmigazete.gov.tr/ [Erişim tarihi: 10.02 .2020$]$

Resmî Gazete 2017-2019. Tarımsal Desteklemelere İlişkin Bakanlar Kurumu Kararı. Erişim: https://www.resmigazete. gov.tr/ [Erişim tarihi:12.06.2020]

Sav O, Sayın C, 2016. Türkiye'de Yağlı Tohumlar Sektörü ve İzlenen Politikalar. 12.Ulusal Tarım Ekonomisi Kongresi, Isparta, 25-27 May1s 2016, sf. 763-770.

Semerci A, Süzer S. 2007. Trakya'da Ayçiçeği Üreten İşletmelerde Girdi Kullanımı ve Destekleme Politikalarının Etkinliğinin Belirlenmesi. (Proje No: Tagem/Ta/05/02/01/ 002, Trakya Tarımsal Araştırma Enstitüsü, Edirne, $135 \mathrm{~s}$.

Semerci A. 2012. Evaluation of The Changes in The Cost Factors of Sunflower Production İn Turkey. Tekirdağ Ziraat Fakültesi Dergisi, 9(3): 54-6.

Semerci A. 2016. Effects of Agricultural Supports on Farmer's Revenue and Product Costs: The Case of Turkey. Custos e @ gronegócio on line, 12(3): 71-96.

Semerci A. 2019a. Yağllk Ayçiçeği Üretiminin Ekonomik Analizi: Kırklareli İli Örneği. Türk Tarım ve Doğa Bilimleri Dergisi, 6(4): 616-623.

Semerci A. 2019b. Cost analysis of oily sunflower production: the case of Tekirdag Province, Turkey. Custos e @gronegócio on line, 15(2): 167-191.

Şahin İ, Semerci A, Kaya Y, Çıtak N. 2010. Ayçiçeği Tarımında Verimlilik ve Destekleme Politikalarının Etkinliğinin Belirlenmesi. (Tarım ve Köyişleri Bakanlığı AR-GE Destekleri Projesi (Proje No: Tagem 08/AR-GE/6). 2010.

TB, 2018. 2018 Y1lı Ayçiçeği Raporu. Gümrük ve Ticaret Bakanlığı. Esnaf, Sanatkârlar ve Kooperatifçilik Genel Müdürlüğü. Erişim: https://ticaret.gov.tr/data/5d41e599 13b87639ac9e02e8/4c17a258a718e4971bfa702f6c03fed3.p df [Erişim tarihi:15.06.2020]

TEAE, 2001. TKB, Tarımsal Ekonomi Araştırma Enstitüsü Yayınları, Proje Raporu 2001-14. Türkiye'de Bazı Bölgeler İçin Önemli Ürünlerde Girdi Kullanımı ve Üretim Maliyetleri.

TOB, 2020. Dünyada Ayçiçeği. Ürün Masaları (Ayçiçeği Bülteni). Tarım ve Orman Bakanlığı. Bitkisel Üretim Genel Müdürlüğü. Tarım Havzaları Daire Başkanlığı. Ankara. Erişim: https://www.tarimorman.gov.tr/BUGEM/Belgeler/ M\%C4\%B0LL\%C4\%B0\%20TARIM/\%C3\%9Cr\%C3\%BC n\%20Masalar\%C4\%B1\%20\%C5\%9Eubat\%20Ay\%C4\%B1 $\% 20 \mathrm{~B} \% \mathrm{C} 3 \%$ BClteni/Ay\%C3\%A7i\%C3\%A7e\%C4\%9Fi\%2 0\%C5\%9Eubat\%20B\%C3\%BClteni.pdf [Erişim tarihi: 15.06.2020]

TOBB, 2020. Türkiye Odalar ve Borsalar Birliği, Borsaya Göre Günlük Fiyatlar. Erişim: https://borsa.tobb.org.tr/fiyat_ borsa.php?borsakod=5ED10 [Erişim tarihi: 10.02 .2020 ]

Top B, Uçum İ. 2016. Durum ve Tahmin (Ayçiçeği 2016/2017). GTHB Tarımsal Ekonomi ve Politika Geliştirme Enstitüsü (TEPGE) Yayınları No: 276, $41 \mathrm{~s}$.

Trakya Birlik 2019. 2019 Yılı Ayçiçeği Ön Alım Fiyatı. Erişim: https://www.trakyabirlik.com.tr/tr/duyurular/haber-detay/ 2019-Yili-Aycicegi-On-Alim-Fiyati/72/1326/0 [Erişim tarihi: 10.02.2020]

TÜİK, 2020. Türkiye İstatistik Kurumu, Bitkisel Üretim İstatistikleri. Erişim: https://biruni.tuik.gov.tr/medas/?kn= 104\&locale $=\operatorname{tr}$ [Erişim tarihi: 10.02.2020]

USDA, 2020. Amerika Birleşik Devletleri Tarım ve Orman Bakanlığı. Oilcrops Year Book. Erişim: https://www.ers. usda.gov/data-products/oil-crops-yearbook/oil-cropsyearbook/ [Erişim tarihi:10.02.2020] 